\title{
The Implementation of Accounting Conservatism Principles
}

\author{
DEVI PERMATASARI* \\ AHMAD RUDI YULIANTO \\ Universitas Islam Sultan Agung
}

\begin{abstract}
This research investigates the influence of Company Growth, Investment Opportunity Set (IOS), and Managerial Ownership toward the application of accounting conservatism principles at mining companies listed in Indonesia Stock Exchange (IDX). This research used secondary data from IDX in 2015-2018. The sample of this research used a purposive sampling technique. Based on purposive sampling method, the number of the samples were 73 companies. The data analysis technique used multiple linear regression analysis. The results of this research show that company growth and managerial ownership have a negative influence on accounting conservatism principle. Meanwhile, the investment opportunity set has a positive influence on the application of accounting conservatism principle.
\end{abstract}

Keywords: Company growth, Investment Opportunity Set (IOS), managerial ownership, accounting conservatism

Abstrak: Penelitian ini dilakukan dengan tujuan untuk menguji dan menganalisis pengaruh Company Growth, Investment Opportunity Set (IOS) dan Managerial Ownership terhadap penerapan prinsip konservatisme akuntansi pada Perusahaan Pertambangan yang terdaftar di Bursa Efek Indonesia. Data yang digunakan adalah data sekunder yang bersumber dari Bursa Efek Indonesia (BEI) dalam rentang waktu 2015-2018. Penentuan sampel dalam penelitian ini menggunakan teknik purposive sampling. Berdasarkan metode purposive sampling, sampel yang diperoleh sebanyak 73 perusahaan. Teknik analisis data menggunakan analisis regresi linier berganda. Hasil penelitian menunjukkan bahwa company growth dan managerial ownership berpengaruh negatif terhadap penerapan prinsip konservatisme akuntansi; dan investment opportunity set berpengaruh positif dan signifikan terhadap penerapan prinsip konservatisme akuntansi.

Kata kunci: Company Growth, Investment Opportunity Set (IOS), Managerial Ownership, dan Konservatisme akuntansi 


\section{Introduction}

According to Indonesia Financial Accounting Standards (IFAS or PSAK) Number 1 (2015) financial report is a structured presentation of the financial position and financial performance in an entity. It is also part of the financial reporting process. One of the principles is the accounting conservatism principle in Financial Accounting Standards (FAS or SAK). The principle of accounting conservatism can be interpreted as a cautious attitude towards risk by willing to sacrifice something in order to reduce risk (Suwardjono, 2014). One of the causes of accounting scandals is the lack of implementation of accounting conservatism in the financial report. One of the cases happened in PT Energi Mega Persada Tbk (ENRG).

The case shows that there is a careless attitude of the management in the presentation of the financial statements so that it results in excess in reporting profits. The company has a high optimistic attitude in recognition of its profits; thus, the presented value is higher than the expected profit. Careless attitude causes financial misstatement, which can cause material errors. This can make the financial statements users make wrong decisions. It is in contrast to the presented financial statements with a cautious attitude. It will give the best benefits for all users of the financial statements, including generating profits.

The accounting conservatism principle is explained through the perspective of agency theory and signal theory (Saputri, 2013). In agency theory, explains the presentation of financial reports that apply accounting conservatism principle will maintain the relationship among parties who have a concern with the company. Based on the perspective of signal theory, the manager gives the company's information through financial reports about the implementation of accounting conservatism principle policy that will result in a higher earning quality and relatively permanent.

Various studies related to the accounting conservatism have been conducted, including research by Andreas et al., (2017), Padmawati, (2015), Quljanah, et al., (2017), Susanto and Ramadhani (2016), Sinambela and Almilia (2018), Pambudi (2017) and Risdiyani (2015). Many factors influence the implementation of 
accounting conservatism principles. Company growth describes the company's ability to improve the scale of its company. A growing company tends to apply the concept of accounting conservatism in its financial reports. The study of Andreas et al. (2017) stated that company growth influences the application of accounting conservatism principle; meanwhile, research by Saputri (2013) shows the results of company growth do not influence the implementation of accounting conservatism principle.

Investment Opportunity Set (IOS) is an overview of investment opportunities for a company. The higher IOS value, the higher market to book ratio as a proxy for accounting conservatism. Research about Investment Opportunity Set (IOS) conducted by Saputri (2013), Dwitayanti, Y., (2015) and Andreas et al., (2017) indicates that Investment Opportunity Set (IOS) has a positive influence towards the implementation of accounting conservatism principles.

Managerial ownership refers to a condition that describes the internal party of a company who have stocks in the company. The research results by Risdiyani (2015) stated that managerial ownership has no significant influence on the implementation of accounting conservatism principle. It is different from the research conducted by Dewi (2014) and Septian (2014), the results show that managerial ownership influence the implementation of accounting conservatism principle.

This research is conducted because the accounting conservatism principle is still relevant to be re-analyzed. It is re-analyzed because there are variables that have inconsistent results such as company growth, investment opportunity set, and managerial ownership. In addition, based on the phenomenon, there are still companies that do not implement accounting conservatism principle, so that it causes financial reports scandal. This scandal, mostly because the company is too optimistic about earning. The results of this study indicated that company growth and managerial ownership negatively affect the application of accounting conservatism principles. Meanwhile, the investment opportunity set has a positive and significant effect on the application of accounting conservatism principles. 
Furthermore, this research is expected to be able to provide empirical evidence about the effect of company growth, investment opportunity set, and managerial ownership on the application level of accounting conservatism principles in mining companies. In addition, this research is also expected to be able to present information about the application of accounting conservatism principles in companies, that can be influenced by company growth, investment opportunity sets, and managerial ownership, and the implications of prudence principle in mining companies. As an additional material, this research is expected to be able to provide an overview of accounting conservatism principles application in Indonesia. The overview can be used as consideration in making economic decisions as investors and potential investors in mining companies listed on the Indonesia Stock Exchange.

\section{Theoretical Framework and Hypothesis Development_Agency Theory}

Agency theory is a theory used by the company as the basis of business practices. The perspective of agency theory can explain the accounting conservatism principle. This research used agency theory because companies that apply accounting conservatism principles in its financial statements have the goal of maintaining a good relationship among parties. The implementation of accounting conservatism is able to reduce the agency's conflict due to information asymmetry (Saputri, 2013).

\subsection{Signal Theory}

Signal theory reveals that management gives a signal in order to reduce information asymmetry. This theory gives a signal to the manager related to the company's future predictions. The implementation of accounting conservatism assesses the prospects of the company. So that, assets and earnings presented are not overstated and does not raise any expectations about big compensations from investors (Affianti, 2017).

\subsection{Accounting Conservatism Principle}

Accounting conservatism principle is a wise principle in determining and presenting the amount of profit, based on the assumption of the company's economic 
uncertainty in the future by acknowledging its cost faster and cautious in recognizing income. LaFond and Watts (2008) also stated that the use of this principle could prevent the asymmetry of information generated from the manipulation of the financial statements.

One of the cases regarding accounting conservatism is a case at PT Energi Mega Persada Tbk (ENRG) in 2010. ENRG made a wrong note in the first quarter of 2010 financial statements. It is in terms of a deposit account at a large company, PT Bank Capital Indonesia Tbk (BACA). In the first financial report issued by ENRG, the deposit funds at Bank Capital Indonesia reached Rp1,136 trillion. ENRG revised the financial statements, and the amount was drastically reduced by Rp1,006 trillion to Rp130 billion (okezone.com). According to research by Syifa (2017), ENRG has a high DER of $100.34 \%$. It means the level of financial health in ENRG is very bad. In addition, ENRG has a low level of managerial ownership, which only reached $0.004 \%$ in 2010. This opens a chance for management not to apply the accounting conservatism principle. So that profit targets are achieved, and the company's performance looks good by shareholders.

\subsubsection{Company Growth}

The company's growth shows the company's ability to increase the company's scale (Risdiyani, 2015). The company's growth can be seen in growth opportunities. Not only chance and opportunities, but the company's growth also needs funds to grow and to balance income and debt. This condition challenges company management.

Companies that are experiencing growth tend to apply the principles of accounting conservatism. The rapid company growth resulted in a greater need for funds for expansion. The greater fund needed by the company; the greater willingness of the company retains its earnings in order to fulfill the company's investment in the future.

\subsubsection{Investment Opportunity Set (IOS)}

Pagalung (2003) states that the investment opportunity set is a set of investment decisions in the form of owned assets and future investment options, which is the 
value of the investment opportunity set itself affect the company value. Saputri (2013) states that companies have some investment opportunities, both tangible and intangible, that are prospective will give an idea to the public that the company has a better growth opportunity when compared to companies that have few investment opportunities.

\subsubsection{Managerial Ownership}

Susanti (2013) defined managerial ownership as a number of shares held by internal companies. Managerial ownership is shares owned by managers and directors of companies. This ownership will align the interests of management and shareholders, because the number of shares owned by the management, will make them more careful in making decisions.

Wulandari (2014) stated that managerial ownership is shared ownership by management as measured by the percentage of the number of shares owned by management. Companies with managerial ownership have different decisions and activities than companies without managerial ownership. A company with managerial ownership has a manager who is also a shareholder, which means that it will align its interests as managers and shareholders. In contrast to companies without managerial ownership, where managers are not both shareholders, likely, the manager will only focus on his interests as a manager.

\subsection{Company Growth}

Company growth is one of the elements in the company's cycle. In order to grow, a company does not only need an opportunity but also needs funds. Ahmed and Duellman (2007) explained that sales growth influences the implementation of accounting conservatism. The high company growth makes the manager uses accounting conservatism so that it minimizes the risk of economic uncertainty in the future. One of the studies from Andreas et al. (2017) explained that company growth has a positive influence on the implementation of accounting conservatism. This result is consistent with the study from Risdiyani (2015).

H1: Company growth has a positive influence on accounting conservatism principle. 


\subsection{Investment Opportunity Set (IOS)}

Investment opportunity set (IOS) is a group of investment decisions in the form of assets and also one of the investment options in the future. The Investment Opportunity Set (IOS) value influences company value. The bigger Investment Opportunity Set value, the bigger market to book ratio as the proxy of accounting conservatism. Otherwise, the smaller investment opportunity set, the smaller market to book ratio as the proxy of accounting conservatism. It is because the market gives a positive reaction towards company growth so that the stock price is increasing. Research about Investment Opportunity Set (IOS) conducted by Saputri (2013), Dwitayanti, Y., (2015) and Andreas et al., (2017) shows that Investment Opportunity Set (IOS) gives positive influence towards the implementation of accounting conservatism principle.

H2: Investment opportunity set gives a positive influence on the implementation of accounting conservatism principle.

\subsection{Managerial Ownership}

Managerial ownership is a number of stocks of the company's internal. Alfian (2013) stated that if the stocks of managerial ownership are bigger than other investors, then management tends to present his financial statements by implementing accounting conservatism. It is because the manager's sense of belonging towards the company is great enough. So, the manager would prefer to expand the company rather than giving a bonus to when the company reaches the earning target. It is supported by the research conducted by Dewi (2014), Pratanda (2014), Septian (2014), and Pambudi (2017). They stated that managerial ownership has a positive influence on the implementation accounting conservatism principle.

H3: Managerial ownership gives a positive influence on the implementation of accounting conservatism principle. 


\section{Research Method}

\subsection{Type of Data}

This research is quantitative research by hypotheses testing. The data used in this research is documentary data in the form of the annual financial report from mining companies listed in Indonesia Stock Exchange (IDX). This research used secondary data and annual financial report during 2015-2018. This research only used financial, an annual report from mining companies to maintain the data homogeneity.

This research took the population from mining companies listed in Indonesia Stock Exchange (IDX) year 2015 to 2018, with 42 companies. The sample is limited in the mining companies in order to maintain the data homogeneity that will be processed. The sampling criteria are as follows: Firstly, the companies were not delisting during 2015-2018. Secondly, companies that have the complete financial report in Indonesia Stock Exchange (IDX) gradually, the year 2015-2018. Finally, the companies have complete data related to the research.

\subsection{Research Operational Variable Definition}

\section{Accounting Conservatism Principle}

The dependent variable in this research is accounting conservatism. The accounting conservatism principle is a precautionary principle. This principle will only acknowledge revenue and expenses when it meets the requirements of revenue recognition and expenses in IFRS. The accounting conservatism principle is a principle introduced by IFRS. The accounting conservatism principle in this research is measured by the market to book ratio (MTB) approach, which refers to research by (Saputri, 2013). Companies with the market to book ratio (the ratio is more than 1) showed that the company implements the accounting conservatism in its annual financial report.

$$
\mathrm{MTB}=\frac{\text { Price }}{\mathrm{EPS}}
$$

Description :

MTB: Market to Book Ratio 
Price: Stock price per sheet year $\mathrm{t}$

EPS: Equity Per Stock

\section{Company Growth}

Company growth is an overview of the company's ability to improve its company scale (Risdiyani, 2015). Company growth is the company able to improve the company size by the improvement of an asset, equity, earning, and sales (Andreas et al., 2017). The company improvement depends on company growth as an independent variable, which is proxied by the sales growth ratio. It is because the higher sales growth, it indicates that the operation activity by the company is getting better. According to Andreas et al. (2017), sales growth can be measured by:

sales growth $=\frac{\text { sales }_{\mathrm{t}}-\text { sales }_{\mathrm{t}-1}}{\text { sales }_{\mathrm{t}-1}}$

\subsection{Investment Opportunity Set (IOS)}

Based on Pagalung (2003) stated that an investment opportunity set is a group of investment decisions in the form of asset and investment options in the future. The investment opportunity set value influences the company value. Generally, IOS is an overview of investment opportunities for the company (Aristantia dan Putra, 2015). Investment Opportunity Set (IOS) as an independent variable in this research used measurement that refers to research by Andreas et al., (2017) as follows:

$$
\text { IOS }=\frac{\text { Fixed Asset Book Value }_{\mathrm{t}}-\text { Fixed Asset Book Value }_{\mathrm{t}-1}}{\text { Total Asset }}
$$

\subsection{Managerial Ownership}

Managerial ownership number of stocks owned by the company's internal Managerial owners hip consists of stockholders who have a position in the company as creditor or board of commissioners. In other words, managerial ownership is the stocks owned by the manager and director of a company. The measurement of managerial ownership in this research refers to research conducted by Risdiyani (2015) and Sarah (2017). They stated that managerial ownership is the percentage of 
the total stocks owned by the company (directors, commissioner, staffs), which is denoted as follows:

$$
\text { Managerial Ownership }=\frac{\text { Number of Managerial Shares }}{\text { Number of outstanding shares }}
$$

\subsection{Analysis Technique}

This study used SPSS 23 for windows application for data analysis. The analysis divided into four stages of the test; they are descriptive statistical analysis, classical assumption test, F test, coefficient of determination (R2), and t-test. This research used multiple linear regression analysis methods to prove the hypotheses that have been qualified for the classic assumption test. The classic assumption test was a normality test, autocorrelation test, multicollinearity test, and heteroscedasticity test. The multiple linear regression equation in this research is as follows:

$$
\mathrm{Y}=\alpha+\beta_{1} \mathrm{X}_{1}+\beta_{2} \mathrm{X}_{2}+\beta_{3} \mathrm{X}_{3}+e
$$

Description:

$\mathrm{Y} \quad=$ Accounting Conservatism

$\alpha \quad=$ Constant

$\beta \quad=$ Independent variable regression coefficient

$\mathrm{X}_{1} \quad$ = Company growth

$\mathrm{X}_{2} \quad$ = Investment opportunity set (IOS)

$\mathrm{X}_{3} \quad=$ Managerial ownership

$e \quad=$ Error term

\section{Result and Discussion}

\subsection{Data Collection Result}

This research took the population from mining companies listed in IDX years 2015 to 2018, with 42 companies. Based on the sample criteria, the samples were 21 mining companies listed in IDX for 4 years, so that the samples obtained were 84 data. Following are the sample distribution in this research: 
Table 1

Sample Distribution

\begin{tabular}{|c|l|c|}
\hline No & \multicolumn{1}{|c|}{ Description } & Total \\
\hline 1. & Mining companies listed in IDX & 42 \\
\hline 2. & The companies were not de-listing during 2015-2018 & 41 \\
\hline 3. & $\begin{array}{l}\text { Companies that have the complete financial report in Indonesia Stock } \\
\text { Exchange (IDX) gradually, the year 2015-2018 }\end{array}$ & 27 \\
\hline 4. & The companies have complete data related to the research. & 21 \\
\hline 5. & Companies that qualified the sample criteria from 2015 to 2018. & 84 \\
\hline 6. & Outlier data & 11 \\
\hline 7. & Research samples total & 73 \\
\hline
\end{tabular}

\subsection{Descriptive Statistic}

A descriptive statistic is a statistic that uses to analyze data by describing the data obtained without making any general conclusion or generalization (Sugiyono, 2012). Following is the descriptive statistic for each research variable:

Table 2

Descriptive Statistics

\begin{tabular}{|l|r|r|r|r|r|}
\hline & $\mathrm{N}$ & Minimum & Maximum & \multicolumn{1}{c|}{ Mean } & Std. Deviation \\
\hline PRDC & 73 & -57.63 & 35.42 & 6.3294 & 25.12640 \\
COGR & 73 & -1.68 & 38.47 & .8734 & 6.86520 \\
IOS & 73 & -.94 & .65 & .1327 & .42184 \\
MO & 73 & .00 & .65 & .0522 & .13978 \\
Valid N (listwise) & 73 & & & & \\
\hline
\end{tabular}

Source: Processed secondary data, 2020

Based on table 2, the average value of accounting conservatism principle implementation is 6.3294. It shows that the implementation of accounting conservatism in mining companies is high because the average variable is more than one. The company growth variable shows that the average is 0.8734 . It shows that the company average in terms of sales is increased by 87.34 percent. The IOS variable has an average value for 0.1327 , and the managerial ownership variable shows the average for 0.0522 . 


\subsection{Classic Assumption Test}

The normality test aims to test whether or not in the regression model, the residual variable has a normal distribution (Ghozali, 2018). In order to identify the assumption of the data normality test, it will use the Kolmogorov-Smirnov test. Based on the table of the normality test by using the Kolmogorov-Smirnov test, it shows a significant result for 0.634 , bigger than 0.05 . Therefore, it can be said that it is distributed normally.

A multicollinearity test is conducted to find out the correlation among the independent variable. It also can detect the multicollinearity in the regression model through the result of VIF (Variance Inflation Factor) and tolerance. The criteria of tolerance value remark the multicollinearity for more than 0.1 and VIF values less than 10. According to the result of the multicollinearity test table, it shows that the independent variable of the research has a tolerance value for more than 0.1 , and the VIF value is smaller than 10 . As a result, there is no multicollinearity in the regression model.

Heteroscedasticity aims to test the regression model. The regression model will be tested about the variance inequality from the residual of one research to another research. The test can be done by scatterplots graphic. The data can be said that there is no heteroscedasticity if the points at scatterplots spread randomly either over or under zero number on the Y-axis (Ghozali, 2018). Figure 1 (Heteroscedasticity test) shows that there is no heteroscedasticity used in this research. It is because the points at scatterplots spread randomly either over or under zero number on the Y-axis.

The autocorrelation test has a goal of the linear regression model that correlates the residual mistake at $\mathrm{t}$-period with a residual mistake at $\mathrm{t}-1$ (previous period). The autocorrelation arises because the sequential observation is correlated with each other. In order to detect the autocorrelation in this research, it used Durbin Watson (DW). Based on the analysis result shown in table 4.5, the Durbin-Watson value is 2.233. In the autocorrelation test table, the $\mathrm{dL}$ value is 1.4778 , and $\mathrm{dU}$ is 1.7691 for $\mathrm{k}=5$ and 
$\mathrm{n}=73$. It means that $\mathrm{dU}<\mathrm{DW}<4-\mathrm{dU}$ is $1.7691<2.1035<2.2309$, therefore it can be said that the variable in this has not autocorrelation.

Table 3

Normality Test

\begin{tabular}{|ll|r|}
\hline & & $\begin{array}{c}\text { Unstandardized } \\
\text { Residual }\end{array}$ \\
\hline $\mathrm{N}$ & Mean & 73 \\
Normal Parameters, ${ }^{\mathrm{b}}$ & Std. Deviation &, 0000000 \\
& Absolute &, 04867220 \\
Most Extreme Differences & Positive &, 063 \\
& Negative &, 054 \\
& &,- 069 \\
Kolmogorov-Smirnov Z & &, 451 \\
Asymp. Sig. (2-tailed) & &, 634 \\
\hline
\end{tabular}
a. Test distribution is Normal.
b. Calculated from data.

Table 4

Multicollinearity Test

Coefficients

\begin{tabular}{|ll|r|r|}
\hline \multirow{2}{*}{ Model } & \multicolumn{2}{|c|}{ Collinearity Statistics } \\
\cline { 2 - 3 } & \multicolumn{2}{|c|}{ Tolerance } & \multicolumn{1}{|c|}{ VIF } \\
\hline $1 \quad$ (Constant) & & \\
& COGR &, 866 & 1,032 \\
IOS &, 946 & 1,047 \\
MO & &, 861 & 1,253 \\
& & & \\
\hline
\end{tabular}

a. Dependent Variable: PRDC 
Figure 1

Scatterplot Graphic

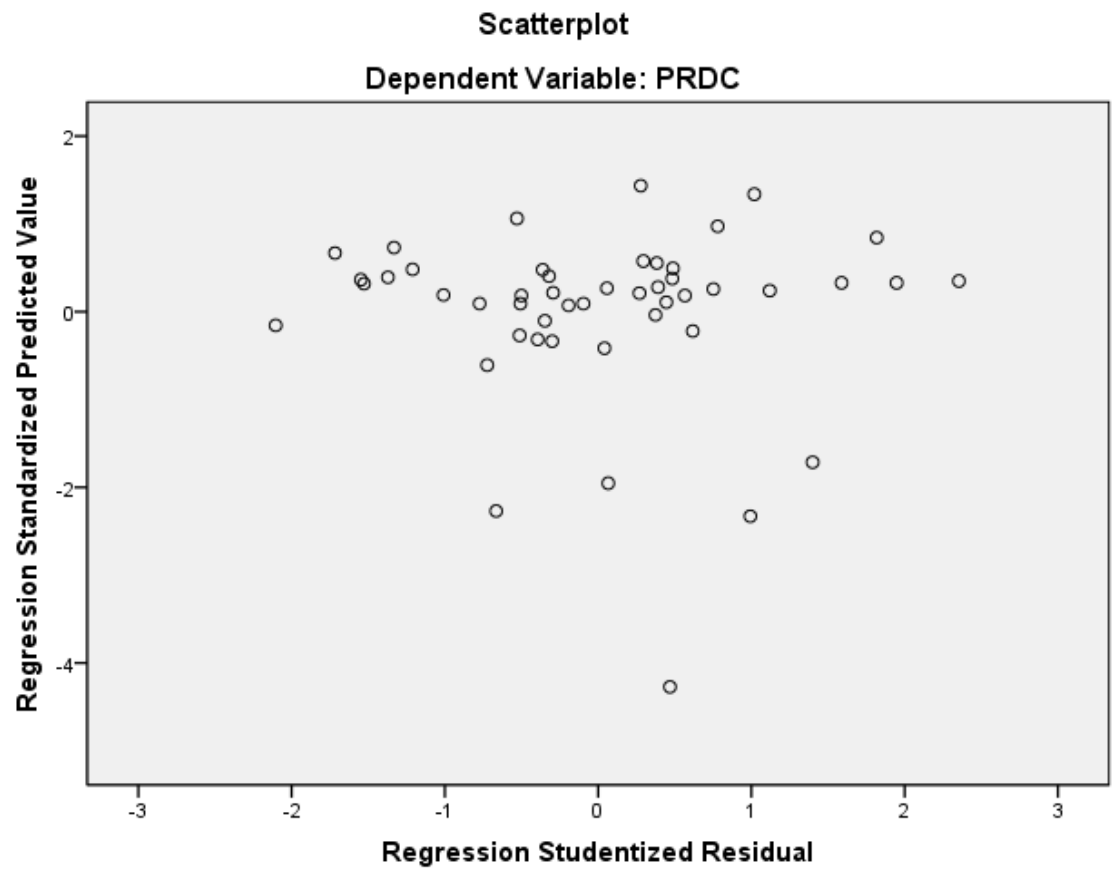

Table 5

Autocorrelation Test

\begin{tabular}{|l|r|c|}
\hline Model & $\begin{array}{l}\text { Std. Error of } \\
\text { the Estimate }\end{array}$ & $\begin{array}{c}\text { Durbin- } \\
\text { Watson }\end{array}$ \\
\hline dimension0 1 &, 04160736 & 2,1035 \\
\hline
\end{tabular}

a. Predictors: (Constant), MO, COGR, IOS

b. Dependent Variable: PRDC

\subsection{F Test Model and Determination Coefficient}

Table 6

F Test and Determination Coefficient

\begin{tabular}{|c|c|c|c|c|}
\hline Sig. & Adjusted $\mathbf{R}$ Square & F & Testing Criteria & Description \\
\hline $\mathbf{0 , 0 0 0}$ & 0,532 & $\mathbf{6 , 5 3 4}$ & Sig. $<\mathbf{0 , 0 5}$ & Significant \\
\hline
\end{tabular}


Based on table 6 it shows that the amount of $\mathrm{F}$ value is 6.534 ; it is stated with a positive sign so that the relationship direction is positive. $P$-value shows a significant result for $0.000(\mathrm{p}<0.05)$. It shows that simultaneously, the independent variable has a significant and positive influence dependent variable. In other words, company growth, IOS, and managerial ownership as the independent variable influence the accounting conservatism.

In table 6, it can be concluded that the adjusted R Square value is 0.532 or 53.2 percent. It means that 53.2 percent variation from accounting conservatism can be explained by company growth, investment opportunity set, and managerial ownership variable. Meanwhile, 46.8 percent of accounting conservatism is explained by other variables outsides of this research.

\subsection{Individual Parameter Significance Test (t-Test)}

Individual parameter significance test ( $\mathrm{t}$ statistic test) is conducted to find out the influence of independent variables towards the dependent variable partially or individually (Ghozali, 2018). The result of this test can is shown in table 7 as follows:

Table 7

T-test

\begin{tabular}{|l|r|r|r|}
\hline \multicolumn{1}{|c|}{ Variable } & Regression Coefficient & \multicolumn{1}{c|}{ T } & \multicolumn{1}{c|}{ Sig. } \\
\hline COGR & $-0,215$ & $-2,749$ & 0,027 \\
\hline IOS & 0,436 & 3,524 & 0,014 \\
\hline MO & $-0,028$ & $-2,936$ & 0,021 \\
\hline
\end{tabular}

The result of the t-test on table 7 , it can be concluded that company growth has a negative influence on the implementation of accounting conservatis $m$ principles. The conclusion rejects the hypotheses in this research. According to table 7, hypotheses rejection is because of the growth of mining companies during the research period. The average company growth in mining companies during the research period was only 0.8734 . From 73 samples, only 17 research samples have sales growth value for more than one, and the rest of 56 companies did not have any sales growth less than 1 . 
Moreover, not all managers implement the accounting conservatism principle by minimizing the earning to fulfill the company investment needs. Some companies use external data to fulfill the investment needs so that there is no urgency to lower the earning by accounting conservatism principles in the financial reports, like what ANTM has been done. Since 2016, ANTM company used 96,37\% from the obligation net revenue 2011 to fund the routine investment and business improvement. This research result is consistent with the research result conducted by Susanto and Ramadhani (2016), who stated that company growth has a positive influence on the implementation of accounting conservatism principle.

The testing result in table 7, can be concluded that the Investment Opportunity Set (IOS) give positive and significant the implementation of accounting conservatism principle in mining companies. Also, the bigger Investment Opportunity Set (IOS), the bigger market to book ratio as the proxy of accounting conservatism principle. Otherwise, the smaller Investment Opportunity Set value (IOS), the smaller market to book ratio value. It is because the market gives a positive reaction toward company growth so that the stock price increase. The increased stock price will make the Investment Opportunity Set value also increase. In other words, market to book ratio value as the proxy of accounting conservatism principle. This research result is consistent with the research of Andreas et al. (2017) stated that the investment opportunity set gives a positive and significant influence on the implementation of accounting conservatism principles.

The results of hypotheses testing show that partially managerial ownership has a negative influence on the implementation of accounting conservatism principles. Theoretically, the low managerial ownership makes the management report higher earning. However, in this research, managerial ownership has a negative influence on the implementation of accounting conservatism. It means that, if managerial ownership is low, the implementation of accounting conservatism is higher and so forth. It is because management with higher managerial ownership chooses not to use accounting conservatism in its annual financial report in order to avoid decrease 
stocks. The company's stocks will decrease if the investor is not interested in investing in the company. Therefore, to attract the investor, the company does not implement accounting conservatism principles in its annual financial report for high earning. Moreover, the average of managerial ownership in mining companies, which becomes the samples of this research, belongs to a low category so that the samples are not representative. The result of this research is consistent with the research by Risdiyani (2015) suggested that managerial ownership has a negative influence on the implementation of accounting conservatism principles.

\section{Conclusion, Limitations, and Future Studies}

Based on the analysis in the 73 companies for four years research period, by using multiple linear regression analysis, the results are as follows: Firstly, company growth gives a negative influence towards the implementation of accounting conservatism principles. This result rejects hypothesis 1 , which stated that company growth has a positive influence on the implementation of accounting conservatism principle. Secondly, the Investment Opportunity Set (IOS) gives a positive and significant influence on the implementation of the accounting conservatism principle. This result accepts hypothesis 2, which stated that the Investment Opportunity Set (IOS) has a positive influence on the implementation of the accounting conservatism principle. Thirdly, managerial ownership has a negative influence on the implementation of accounting conservatism principles. This result rejects hypothesis 3, which stated that managerial ownership has a positive influence on the implementation of accounting conservatism principle.

\subsection{Limitation and Future Studies}

This research has some limitations. Firstly, the period of this research is only three years, so that the analysis is not deep. Secondly, this research is limited to mining companies only so that there is no generalization for all kinds of industries. 
Finally, this research did not examine all variables that allegedly influential towards the implementation of the accounting conservatism principle.

To improve the generalizability of the study's findings, future study is suggested to use a more extended research period so that it can strengthen the research result. Study in other industries, such as banking and service industry, may also provide exciting findings. Finally, other variables that allegedly influential towards the implementation of accounting conservatism principles, capital intensity, or litigation function may be examined in future studies.

\section{References}

Affianti, D. (2017). Pengaruh Good Corporate Governance, Ukuran Perusahaan, Leverage dan Profitabilitas terhadap Tingkat Konservatisme Akuntansi pada Industri Perbankan. Jurnal STIE Perbanas Surabaya.

Ahmed, A. S., \& Duellman, S. (2007). Accounting conservatism and board of director characteristics: An empirical analysis. Journal of Accounting and Economics, 43(2-3), 411-437. https://doi.org/10.1016/j.jacceco.2007.01.005

Alfian, A. dan A. (2013). Analisis Faktor-Faktor yang Berpengaruh Terhadap Pemilihan Konservatisme Akuntansi. Diponegoro Journal Of Accounting, 2(3), 123-132.

Andreas, H. H., Ardeni, A., \& Nugroho, P. I. (2017). Konservatisme Akuntansi di Indonesia. Jurnal Ekonomi Dan Bisnis, 20(1), 1. https://doi.org/10.24914/jeb.v20i1.457

D. Aristantia dan I. M. P .D. Putra. (2015). Investment opportunity set dan Free cash flow pada Tingkat Pembayaran Dividen Perusahaan Manufaktur. Jurnal Akuntansi Universitas Udayana, 11(1), 220-234.

Dewi, N. K. S. L. dan I. K. S. (2014). Pengaruh Struktur Kepemilikan Manajerial, Leverage, dan Financial Distress terhadap Konservatisme Akuntansi. E-Journal Akuntansi Universitas Udayana, 7(1), 223.

Dwitayanti, Y., dan R. F. (2015). Pengaruh kepemilikan manajerial, investment opportunity set, price to book ratio, dan political cost terhadap konservatisma akuntansi. Jurnal Akuntanika, 2(1), 31-43.

Ghozali, I. (2018). Aplikasi Analisis Multivariate dengan Program IBM dan SPSS. Semarang: Unoversitas Diponegoro.

LaFond, R., \& Watts, R. L. (2008). The information role of conservatis m. Accounting Review, 
83(2), 447-478. https://doi.org/10.2308/accr.2008.83.2.447

Padmawati, I. R. dan F. (2015). PENGARUH MEKANISME GOOD CORPORATE GOVERNANCE DAN KUALITAS AUDIT TERHADAP TINGKAT KONSERVATISME AKUNTANSI. Accounting Analysis Journal, 4(1). https://doi.org/10.15294/aaj.v4i1.7810

Pagalung, G. (2003). Pengaruh Kombinasi Keunggulan dan Keterbatasan Perusahaan terhadap Set Kesempatan Investasi (IOS). Jurnal Riset Akuntansi Indonesia, 6(3), 249-263.

Pambudi, J. E. (2017). Pengaruh Kepemilikan Manajerial Dan Debt Covenant Terhadap Konservatisme Akuntansi. Competitive Jurnal Akuntansi Dan Keuangan, 1(1), 87. https://doi.org/10.31000/competitive.v1i1.109

Pratanda, R. S. dan K. (2014). Pengaruh Mekanisme Good Corporate Governance, Likuiditas, Profitabilitas, dan Leverage terhadap Konservatisme Akuntansi. Accounting Analysis Journal, 3(2). https://doi.org/10.15294/aaj.v3i2.4256

Quljanah, M., Nuraina, E., \& Langgeng Wijaya, A. (2017). Pengaruh Growth Opportunity Dan Leverage Terhadap Konservatisme Akuntansi (Studi Empiris Perusahaan Manufaktur Terdaftar Di Bei). Forum Ilmiah Pendidikan Akuntansi, 5(1), 477-489.

Risdiyani, F. dan K. (2015). Analisis Faktor-Faktor Yang Mempengaruhi Penerapan Konservatisme Akuntansi. Accounting Analysis Journal, 4(3). https://doi.org/10.15294/aaj.v4i3.8305

Saputri, Y. D. (2013). Faktor-faktor yang Mempengaruhi Pilihan Perusahaan terhadap Konservatisme Akuntansi. Accounting Analysis Journal, 2(2).

Sarah, E. (2017). Pengaruh Leverage, Kepemilikan Manajerial, dan Financial Distress terhadap Konservatisme Akuntansi (Studi Pada Perusahaan Sektor Pertambangan yang Terdaftar di BEI Periode 2010-2015). Jurnal Universitas Telkom Bandung.

Septian, A. dan Y. D. A. (2014). Pengaruh Kepemilikan Manajerial, Ukuran Perusahaan, Debt Covenant, dan Growth Opportunities terhadap Konservatisme Akuntansi (Studi pada Sektor Industri Farmasi yang Terdaftar di Bursa Efek Indonesia Tahun 2008-2012). EProceeding of Management, 1(3).

Sinambela, M. O. E., \& Almilia, L. S. (2018). Faktor-faktor yang mempengaruhi konservatisme akuntansi. Jurnal Ekonomi Dan Bisnis, 21(2), 289-312. https://doi.org/10.24914/jeb.v21i2.1788

Sugiyono. (2012). Metode Penelitian Kombinasi (Mixed Methods). Bandung: Alfabeta.

Susanti, S. dan I. B. R. (2013). Pengaruh Good Corporate Governance terhadap Corporate Social Responsibility pada Perusahaan Cosmetics and Household. Jurnal Ilmu Dan Riset Akuntansi, 1(1). 
The Indonesian Journal of Accounting Research - Jan, Vol. 23, No.1, 2020

Susanto, B., \& Ramadhani, T. (2016). Faktor-Faktor Yang Memengaruhi Konservatisme (Studi pada Perusahaan Manufaktur yang Terdaftar di BEI 2010-2014). Jurnal Bisnis Dan Ekonomi, 23(2), 142-151.

Suwardjono. (2014). Teori Akuntansi Perekayasaan Laporan Keuangan. Yogyakarta: BPFE.

Syifa, H. M. (2017). Pengaruh Financial Distress, Kepemilikan Institusional, dan Profitabilitas terhadap Konservatisme Akuntansi (Studi a Perusahaan Food and Beverages yang Terdaftar Di Bursa Efek Indonesia Tahun 2011-2015). Jurnal Universitas Telkom Bandung.

Wulandari, I. (2014). Pengaruh Struktur Kepemilikan Manajerial, Debt Covenant dan Grow th Opportunities terhadap Konservatisme Akuntansi. JOM Fekon, 1(2). 